\title{
Peculiarities of Work With Foreign Students: Problems and Ways to Solve Them
}

\author{
Tatiana Nikolaevna Shurukhina ${ }^{1}$, Olga Nikolaevna Ivus ${ }^{2}$, Alexander Nikitovich \\ Belov $^{3, *}$, Natalia Viktorovna Repsh ${ }^{4}$, Svetlana Anatolyevna Berseneva ${ }^{2}$, Svetlana \\ Ivanovna Maksimenko ${ }^{5}$
}

\author{
${ }^{I}$ Department of Pedagogy, Far Eastern Federal University, Vladivostok, Russia \\ ${ }^{2}$ Primorskaya State Academy of Agriculture, Ussuriysk, Russia \\ ${ }^{3}$ Department of Natural Science Education, Far Eastern Federal University, Vladivostok, Russia \\ ${ }^{4}$ Department of Geography, Ecology and Children's Health, Far Eastern Federal University, Vladivostok, Russia \\ ${ }^{5}$ Academic Methodoligical Department, Far Eastern Federal University, Vladivostok, Russia \\ *Corresponding author. Email: belov.an@dvfu.ru
}

\begin{abstract}
The article covers some issues of international activity of Russian universities. The task of the study described in the article is to identify and describe the real range of problems in the work of teachers of the Primorskaya State Academy of Agriculture with foreign students, and to determine possible ways to solve them. The most important socio-cultural problems of foreign students in the course of their studies are noted. Studying the problems of foreign students studying at the Maritime Agricultural Academy makes it possible to determine their impact on adaptation to the educational process of the university. The obtained data help to more consciously and purposefully design and build the social and educational environment of the academy.
\end{abstract}

Keywords: foreign students, training of foreign students, language barriers, religious and cultural differences, motives of stay in a university, violation of migration legislation, organization of practice

\section{INTRODUCTION}

The implementation of state tasks in the field of higher education aimed at increasing the competitiveness of Russian universities and the development of the export of educational services $[1,2]$ made it possible for Russian universities not only to actively attract foreign students, but also to help improve both the economic condition of the university and the country's economy as a whole.

In order to implement the Decree of the Resolution of the Government of the Russian Federation No. 662 of 5 August 2013 "On the Implementation of Monitoring of the Education System", the Order No. 222 of the Ministry of Education and Science of the Russian Federation of 13 March 2017 "On Monitoring the Education System", according to the Letter about the Ministry of Education and Science of Russia No. ЛО-544/05 of 14 March 2017, the Department of State Policy in the Field of Higher Education collects information on the effectiveness of educational institutions of higher education. International activity, that is, the presence of foreign students, is one of the main indicators of the effectiveness of a university.

\section{METHODOLOGY}

The research methodology was the analysis of federal documents regulating the functioning of Russian education in the context of the export of educational services, creating conditions for the attractiveness of education for foreign students [1-5], as well as scientific works representing various aspects of educational interaction with foreign students. Aref'ev A. L. made an analytical review of the state of Russian education in terms of the provision of educational services to foreigners in his studies [6, 7]. Many scientific works are devoted to the problems of adaptation and cultural interaction with foreign students. These problems are considered by the following scientists Aref'ev A. L. [6], Babadzhanova N. S. [8], Devlikamova I. N. [9], Drozhzhina D. S. [10], Ivanchin S. A. [11], Kapezina T. T. [12], and many others. Works examining the problems of Russian as a foreign language are of particular interest. Babadzhanova N. S. [8], Vasil'eva T.V. [13], Tekucheva I.V. [14] and others reveal the features of the language training of foreign students at the university, as well as 
studies on the problems of social and cultural interaction in multinational societies [15-17].

\section{RESULTS AND DISCUSSION}

An analysis of the export of educational services shows that the threshold value of international activity for universities in the Far Eastern Federal District is set at
$1 \%$, i.e. the presence of foreign students in effective work at the university should not be less than $1 \%$. To achieve this indicator, the Primorskaya State Academy of Agriculture (hereinafter referred to as the Academy) annually carries out a number of activities to attract potential foreign applicants to enter existing accredited training areas.

Table 1 The proportion of the number of foreign citizens studying in the basic educational program of higher professional education at Primorskaya State Academy of Agriculture

\begin{tabular}{|c|c|}
\hline Year & \% \\
\hline 2014 & 4,2 \\
\hline 2015 & 5,49 \\
\hline 2016 & 7,26 \\
\hline 2017 & 8 \\
\hline 2018 & 8,6 \\
\hline 2019 & 9,7 \\
\hline
\end{tabular}

The table below shows that the proportion of the number of foreign citizens studying under the main educational program of higher professional education at the Academy is growing every year.

In 2019 , foreign students were distributed by country as follows:

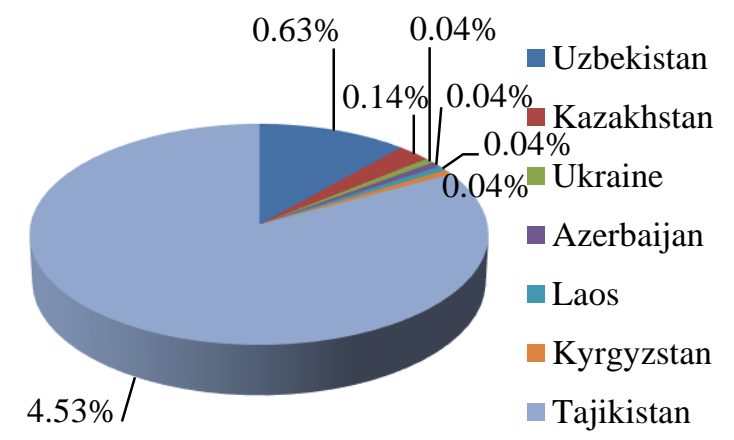

Figure 1 Distribution of the number of foreign students by country of arrival

Most foreign students are citizens of the CIS (Tajikistan). This is due to the fact that the Agreement on cooperation in the field of education was concluded between Primorskaya State Academy of Agriculture and the Technological University of Tajikistan in April 2013.
Meanwhile, the statistics do not include students who have dual citizenship. If such students were taken into account, the proportion of the number of foreign students would double.

Long-term experience shows that foreign students are a special contingent requiring close attention $[6,7,9-12$, 18]. Each teacher and employee at the university, working with foreign students, faces a number of problems that we have identified and analyzed.

We identified the following problems among many others:

1. Language barriers

As we noted above, the majority of foreign students are Tajiks. A decade ago, the percentage of those who do not speak Russian and do not understand Russian was relatively small, since Tajikistan first became part of the USSR, and then became a member of the CIS. The Russian language in this country was the language of interethnic communication. Since 2009, Tajikistan adopted the Law on the State Language of Tajikistan, which replaced the 1989 Law on Language. In the new law, the Russian language is not endowed with the status of the language of interethnic communication. In accordance with this law, all educational and military institutions carry out work only in the national language. Thus, today every second student who comes to Russia does not know the Russian language and needs to learn it. Tajik students coming to Russia find themselves in a different language environment and mastering the language presents great difficulties for them. It is worth noting that the Tajik language belongs to the Iranian branch of the Indo-European family of languages, i.e. is the language of distant kinship for the Russian language (Russian belongs to the Slavic group of the Indo-European 
family of languages). Meanwhile, as researchers note, a successful mastery of the Russian language for teaching a specialty is possible if the student actively owns skills in four types of activities: listening, reading, speaking and writing $[7,8,13,14]$.

Part of the language barriers is removed due to the introduction of various specialties in the curriculum "Russian language and culture of speech", which is studied for one semester in the first year and allows foreign students to facilitate the process of adaptation to the learning process.

In order to overcome language barriers, the Academy sets the task of "immersing" foreign students in the cultural environment of the university. Firstly, such students are accommodated in university dormitories exclusively with Russian students. The language environment in all spheres of life helps to learn any foreign language much faster. Secondly, free foreign language courses are organized for foreign students in the afternoon. In addition, the curators of the groups attract foreign students to participate in general academic events, $80 \%$ of foreign students go in for sports under the guidance of trainers who speak only Russian, some of the foreign students join volunteer groups. The abovementioned measures allow solving the problem of Russian language proficiency by the 2-3 academic year, especially with special vocabulary.

2. Religious and cultural differences

Foreign students coming to another country are forced to learn new cultural patterns. Old patterns and behavior are not always applicable in the new environment, and therefore efforts are required to overcome barriers and integrate students into the new sociocultural environment. One of the cultural characteristics of Russia, which is hard for foreign students to get used to, is the presence of equal rights for women in society. According to the national tradition of the Republic of Tajikistan, a woman is a mother and wife, who is engaged in a home and necessarily reveres men. The word man for women in eastern countries is the law. Women occupy a large share of the leadership in many Russian universities / organizations; women make decisions, establish the work of their structural unit, and also give advice or instructions to students. International students need time to understand that they are forced to listen to a female leader, to fulfill her orders and requirements in Russia. Teachers and curators of groups have to carry out educational work, explain the features of European culture.

Specific features include the sympathy of foreign students for the ideas of radical Islamism and terrorism. Such ideas can be broadcast orally, distributed among students through prohibited sites and online resources. To solve this problem, employees of the bodies of the Ministry of Internal Affairs and the Federal Security Service are connected to the educational process. Teachers conduct curatorial work on preventing the idea of extremism.

3. The goals and motives of studying at a university

Russian higher education is one of the fundamental in the world. This fundamental nature makes Russia attractive to foreigners from neighboring countries who are eager to come to study and get a quality education. If the main purpose of entering a university for foreign students is to get an education in one of the selected educational programs, then there are no problems with such students. They make every effort in order to establish themselves, to become the best. It is important for such students that their family be proud of them. Such students have high rates in educational, scientific, sports and public work. Also, they receive several types of scholarships (regular academic scholarship, advanced academic scholarship, scholarship of the Governor of Primorsky Krai); students parents receive letters of appreciation for the worthy education of their child at the end of each school year; such students are placed on the board of honor by decision of the student council.

Another attractive side for foreign citizens is to enter Russian universities without passing the Russian Unified State Exam (including without the Russian Unified State Exam in Russian), according to the internal tests of the university, which are much easier than passing the Russian Unified State Exam for a Russian student. Unfortunately, the training program in agriculture and forestry is far from prestigious among modern youth, not only in the Russian Federation, but also abroad. $70 \%$ of applicants to an agricultural university in the Russian Federation are applicants who have not passed rigorous competitive selection in their country or their financial situation in their families has prevented their child from studying at a national university. For such a student, enrolling in a university in the Russian Federation is a chance to get higher education at the expense of budgetary allocations from the federal budget of the Russian Federation, the opportunity to receive a scholarship, "gain a foothold" in the country, and obtain Russian citizenship. An additional bonus is the provision of university dormitories to all needy students, the payment for which is less than ten times a rented apartment.

Students begin to work, taking advantage of the law provided by the law of the Russian Federation 115- $\$ 3$ as of July 25, 2002 "On the Legal Status of Foreign Citizens in the Russian Federation", which allows foreign citizens to study at a university full-time only in their free time (after class classes or during the holidays). Such students are a tidbit for employers, as the problem with their residence and migration registration has been resolved (these issues are solved by employees of the international relations department), taxes are not paid, and wages are lower than for Russian citizens. Gradually, many students decide to work full time, which entails missed classes, violations of the Charter of the university, the migration legislation of the Russian Federation. Conversations with such students show that they did not come to study, but to earn money, because they send $90 \%$ of their income to their families who are without work at home. Students are fully aware of the danger of the situation; they realize that their entry will be prohibited for up to 5 years in case of 
deportation from the Russian Federation, but they run the risk.

Unfortunately, another reason pushing foreign students to violate the law may be "failed" exams. Students are deprived of the opportunity to receive even the usual academic scholarship without passing the session on time, having received "satisfactory" for any exam. Thus, foreign students are forced to work without financial support for a semester. In this regard, university employees have to constantly monitor the academic performance of foreign students, organize additional courses for them in some disciplines, trying to help them master individual disciplines. The supervisors of theses, term papers spend twice as much time on foreign students to get the final result.

Another motive of foreign students is the desire to obtain citizenship of the Russian Federation and the opportunity to take advantage of the State program to facilitate the voluntary resettlement of compatriots living abroad in the Russian Federation. This program helps to relocate all family members to Russia at the expense of the federal budget and makes it possible to receive housing allowances, i.e. "Lifting" and a number of other advantages.

4. Violation of migration law

This problem was mentioned above. Entrants face difficulties with the migration order when crossing the border. Students poorly understanding the Russian language, when asked about the purpose of their stay in Russia at customs, give an unintelligible answer, which leads to a migration card, which indicates the purpose of the stay is work, not study. As a result, it is impossible to register such students with migration registration and make them temporary registration at a university dormitory. They are forced to cross the border again to receive a migration card for study, which entails problems both for the university (at the time of entrance examinations, the university admissions committee prepares a letter for each foreign applicant for customs inspectors) and for the student himself.

Another problem of foreign students is their failure to comply with administrative regulations for violations. Such students may be deported due to non-payment of fines on time; or students are forced to cross the border again because of a delay in renewing their registration.

To address these issues, students organize meetings together with representatives of the migration service, where all explanations and warnings are given. The staff of the International Relations Department is doing everything possible to track all students and try to prevent violation of the legislation of the Russian Federation, since all responsibility for the stay of foreign citizens for the period of study lies with the university.

\section{CONCLUSIONS}

Thus, employees have to solve difficult tasks to fulfill the university's performance indicator as the presence of foreign students. Close-knit operational work of the entire team is important for the successful adaptation of foreign students and ensuring a high-quality educational process of the result. For example, an employee of the international department is responsible for organizing compliance with the migration regime (applying for a migration regime, deregistration, issuing invitations, visas, etc.); the curator monitors performance, attendance, etc., conducts curatorial work. The main task of the entire teaching staff is to promote the social unity of foreign students with the entire student society of the university, not to allow them to divide into "friends" and "strangers", to send students to exciting learning, interesting science, fun successful student life (visiting a sports club, creative studios, volunteer and construction teams).

Summing up the above, it can be noted that Russia was and remains attractive for obtaining education not only for students of foreign countries, but also for CIS countries, as Russia has rich experience in fundamental education, low cost of education. Therefore, a clear coordination of the work of all key entities at the federal and regional levels is important for the professional community.

\section{REFERENCES}

[1] Concept of long-term socio-economic development of the Russian Federation for the period up to 2020. Order of the Government of Dews. Federation 17.11.2008. № 1662-p., Collection of Legislation of the Russian Federation No 47.

[2] Passport of the priority project "Development of export potential of the Russian education system (approved by the Presidium of the Council under the President of the Russian Federation on Strategic Development and Priority Projects, Protocol No. 6 of May 30, 2017), Available at: http://www.consultant.ru/document/cons_doc_LAW_2 $17871 /$.

[3] Letter about the Ministry of Education and Science of Russia No. ЛО-544/05 of 14 March 2017, Available at: http://gzgu.ru/doc/vpo1_monitor/2017/p1.pdf.

[4] Resolution of the Government of the Russian Federation No. 662 of 5 August 2013 "On the Implementation of Monitoring of the Education System, Available at: http://www.garant.ru/products/ipo/prime/doc/70329494 /. 
[5] Order No. 222 of the Ministry of Education and Science of the Russian Federation of 13 March 2017 "On Monitoring the Education System, Available at: http://gzgu.ru/doc/vpo-1_monitor/2017/pr1.pdf.

[6] A.L. Arefyev, F.E. Sheregi, (2016). Foreign students in Russian universities. Section One: Russia on the international education market. Section two: Formation of a pool of foreign students for Russian universities, Ministry of Education and Science of the Russian Federation, Center for Sociological Research, 2016.

[7] A.L. Arefyev. Chinese students in Russia, Higher education in Russia 12 (2010) 54-66.

[8] N.S. Babadzhanova. Intercultural interaction as a factor of socialization of foreign students, in: Crosscultural communication in the modern world: proceedings of III Interuniversity scientific and practical conference of foreign students, Penza, 2014, pp. 106-110.

[9] I.N. Devlikamova, S.A. Ivanchin. Cross-cultural communication in the modern world: proceedings of III Interuniversity scientific and practical conference of foreign students, Penza state University, 2014.

[10] D.S. Drozhzhina. Studying the Adaptation of Foreign Students: A Discussion on Methodology: Empirical Research, Universitas 1(3) (2013) 33-47.

[11] I.L. Bekker, S.A. Ivanchin. Problems of adaptation of foreign students to the educational process of the Russian university (on the example of Penza State University), News of higher educational institutions. Volga region region. Humanities 4(36) (2015) 247-257.

[12] T.T. Kapezina. Problems of teaching foreign students in higher education institutions, Science. Society. State 1(5) (2014), Available at: elibrary_22842132_42582375.pdf.

[13] T.V. Vasilyeva. Lingvodidactic concept of teaching Russian language to foreign students of the first year with weak language and subject training in universities of engineering profile: diss.. cand., 2000.

[14] I.V. Tekucheva. Current problems of the methodology of teaching Russian language and Russian language as a foreign language: collective monography, Sputnik+, 2016.
[15] M. Nesterova, M. Dielini, A. Zamozhskyi. Social cohesion in education: cognitive research in the university community, International Journal of Cognitive Research in Science, Engineering and Education 7(2) (2019) 19-27.

[16] M. Nesterova. EU intercultural dialog studies and social cohesion development. Ukraine-European Union: From Partnership Towards Association. The Ukrainian Yearbook of the Europe - an Integration Studies III, Lutsk, Teren, 2019.

[17] I. Sasson. Building a sustainable universitycommunity partnership: case study in science education. Studies in Higher Education, (2018) 1-15. DOI: https://doi.org/10.1080/03075079.2018.1496410

[18] A.L. Arefyev. Export of Russian education: main indicators and trends, Higher education in Russia 1 (2010) 125-141. 